\title{
KONSTRUKSI IDENTITAS BUDAYA KEINDONESIAAN DALAM WACANA BUKU TEKS SEKOLAH DASAR
}

\author{
Dadang S. Anshori \\ Universitas Pendidikan Indonesia \\ Email: dadanganshori@upi.edu \\ DOI: http://dx.doi.org/10.17509/bs_jpbsp.v16i2.4479
}

\begin{abstract}
Abstrak
Penelitian ini bertujuan mengidentifikasi konstruksi identitas budaya keindonesiaan dalam buku teks sekolah dasar kurikulum 2013. Identitas budaya keindonesiaan semakin penting mengingat akhir-akhir ini konflik sosial semakin mengkhawatirkan dan terjadi dalam setiap dimensi kehidupan masyarakat. Konflik terjadi antarkelompok masyarakat terdidik maupun tidak terdidik karena berbagai faktor penyebab. Penelitian ini menggunakan analisis isi teks melalui penggunaan kata dan kalimat sebagai basis analisis. Data yang dianalisis adalah wacana buku teks kelas 1 sekolah dasar sebanyak empat tema. Hasil penelitian ini menunjukkan buku teks menggambarkan identitas budaya keindonesian dalam berbagai bentuk kegiatan dan peran yang dilakukan tokoh ceritadan melekat pada masing-masing peran sesuai dengan setting yang dirancang penulis buku. Penggunaan bahasa sebagai representasi identitas budaya keindonesian digambarkan dalam bentuk kata dan kalimat atau wacana sesuai identitas budaya yang digambarkan. Identitas budaya keindonesian yang dideskripsikan mencakup identitas religius, humanis, sosialis, sportif, toleransi, gotong royong, disiplin, optimis, dan rasional. Ideologi yang dibentuk dalam buku teks bermuara pada ideologi religius, ideologi sosial-humanis, ideologi pluralis-toleran, dan ideologi kemandirian.
\end{abstract}

Kata kunci: konstruksi, tatabahasa, identitas, ideologi, wacana, buku teks

\begin{abstract}
The objectives of research are identified the Indonesia culture identity constructed in primary schools textbooks with curriculum 2013. The Indonesia culture identity was very important while considering social conflict today very apraid and doing in every social life dimention. The conflict was become between scholar social community also unscholar social community with be at the bottom of variation. The study used text content analysis through words and sentence as based analysis. The analysis of data are discourse of textbooks grade one primary schools amounted four theme. The research finding that textbooks represented Indonesia culture identity in all activity and the action has doing by the stories actor which are cheave to each action as well setting as planning of writer textbooks. The language used as Indonesia identity representation described in words and sentence or discourse as well depicted identity. The Indoensia culture identity has description e.g. religious identity, humanism, socialism, sportive, toleration, works in together, discipline, optimist, and rational. The ideology has making in textbooks based on ideology reliogius, social-humanism ideology, toleration-pluralism ideology, and independenty ideology.
\end{abstract}

Keywords: contruction, grammar, identity, ideology, discourse, textbook 


\section{PENDAHULUAN}

Globalisasi dimaknai sebagai perubahan kualitatif dalam tata sosial umat manusia (Heryanto, 2000: 199). Akulturasi yang semula dilakukan untuk menghadirkan keharmonisan global, mengingat manusia semakin dipersatukan dengan teknologi informasi, pada kenyataannya memunculkan petaka persaingan budaya "kalah-menang". Kondisi demikian memungkinkan etnis, komunitas, atau bangsa tertentu kehilangan identitas budaya aslinya karena teralienasi oleh budaya baru yang lebih dominan dan superioritas. Gejala ini diperparah oleh fakta, banyak budaya yang diakomodasi masyarakat bukanlah budaya yang sesuai dengan karakter etnis atau bangsa tersebut, melainkan karakter yang manipulatif.

Kemungkinan terjadinya konflik antaretnis dan budaya dalam masyarakat Indonesia jauh-jauh hari sudah diingatkan antropolog Koentjaraningrat (1990: 384) bahwa keragaman etnis Indonesia berpotensi menimbulkan konflik. Setidaknya ada empat hal yang harus diperhatikan dalam menganalisis kondisi etnis dan budaya di Indonesia, yaitu (1) sumber-sumber konflik, (2) potensi untuk toleransi, (3) sikap dan pandangan etnis atau golongan terhadap sesama etnis dan golongan, dan (4) tingkat masyarakat, tempat etnis atau golongan tersebut hidup. Cara pandang ini tentu saja hingga kini relevan mengingat relasi sosial antarentnis di Indonesia mulai dirasakan disharmoni dan menimbulkan ledakan konflik sosial seiring semakin pluralnya pandangan kebangsaan di masyarakat kita.

Konflik sosial semakin mengkhawatirkan dan terjadi dalam setiap dimensi kehidupan pada setiap lapisan masyarakat. Konflik terjadi antarkelompok masyarakat terdidik maupun tidak terdidik karena berbagai faktor penyebab. Konflik sosial pada 2013 semakin meningkat. Menurut catatan Indonesia Police Watch (IPW) (Pikiran Rakyat, 6 Januari 2014: 1) terdapat enam provinsi yang berkategori rawan konflik sosial, yaitu Papua, Jawa
Barat, DKI Jakarta, Sumatera Utara, Sulawesi Tengah, dan Jawa Tengah.

Secara institusionalitas kondisi konflik sosial ini dikontribusi sistem politik dan kinerja lembaga politik dan pemerintah pascareformasi. Kebebasan berpendapat dan otonomi daerah juga melahirkan ekses negatif, munculnya sikap sektarian (primordial) dan liberarisasi informasi. Suasana kebangsaan demikian berpotensi menimbulkan kekerasan sosial. Berdasarkan hasil survai Cirus Surveyors Group (Pikiran Rakyat, 6 Januari 2014: 2), gejolak sosial yang terjadi di masyarakat dipicu oleh persoalan ekonomi, yakni kemiskinan (44,3\%), pengangguran $(37,2 \%)$, aliran keagamaan $(6,7 \%)$, dan konflik antaretnis $(4,1 \%)$.

Dalam kondisi masyarakat demikian menjadi relevan mengangkat kembali politik identitas budaya dalam wacana kebangsaan Indonesia. Politik identitas tentu saja harus dipahami sebagai upaya mengukuhkan dan merevitalisasi "kejatidirian" masyarakat Indonesia dalam persaingan global, yang dalam bahasa pendidikan nasional disebut sebagai "manusia Indonesia yang berkarakter". Ikhtiar menghadirkan kembali "kejatidirian" tersebut dilakukan secara politik oleh pemerintah melalui kurikulum 2013 yang berimplikasi pada berbagai instrumen pendidikan lainnya seperti buku ajar (texbook). Buku ajar atau buku teks dalam konteks ini merupakan perpanjangan dari misi pendidikan sesuai rumusan kurikulum yang dikendalikan pemerintah (Perdana, 2013: 70). Sebagai sebuah teks, transformasi identitas budaya yang hendak dibentuk dalam buku ajar dilakukan melalui simbol-simbol bahasa.

Bahasa seperti dikemukakan Clark (1996:3) tercermin dalam gabungan aktivitas manusia (language use is really a form of joint action). Istilah joint action atau joint activity yang dikemukakan Clark (1996:30) terinsiprasi pandangan Levinson tentang tipe-tipe aktivitas yang maknanya sejajar dengan istilah "speech event", "episode", "form of life", dan "language games". 
Tipe-tipe aktivitas berbahasa dapat dilihat dari aspek kebertulisan (scriptedness), keformalan (formality), keverbalan (verbalness), kekooperatifan (cooperativeness), dan kepenguasaan (governance). Melalui tipetipe aktivitas berbahasa tersebut akan memunculkan keragaman orang berbahasa yang menunjukkan identitas budaya masing-masing.

Identitas budaya keindonesiaan dalam konteks bahasa dapat tercermin dalam penggunaan bahasa Indonesia sebagai entitas sebuah bangsa, selain tercermin dalam penggunaan bahasa untuk kepentingan pendidikan. Praktik pendidikan merupakan beragam aktivitas manusia yang melibatkan bahasa. Interaksi antara guru dan peserta didik tercipta melalui penggunaan bahasa. Demikian pula antara guru atau peserta didik dengan buku teks. Visi dan misi pendidikan tertransformasi melalui penggunaan bahasa. Media bahasa menjadi alat efektif untuk menyampaikan cita-cita mulia pendidikan.

Mengingat pentingnya hal di atas, kajian atas konten buku teks yang mendukung terciptanya identitas keindonesiaan menjadi penting keberadaannya. Namun, apakah buku teks pelajaran SD mengandung identitas budaya keindonesiaan yang ideal dan identitas apakah yang tercermin (eksplisit maupun implisit) dalam buku teks tersebut menjadi pertanyaaan yang harus dikaji keberadaannya. Pertanyaan tersebut merupakan kajian penting dalam analisis wacana, mengingat wacana (dipahami sebagai bahasa) merupakan media yang efektif untuk menyampaikan sebuah kepentingan politik identitas. Melalui bentuk-bentuk lingual dan tentu sesuai dengan visi pemerintah, buku teks menjadi alat untuk membangun kesadaran peserta didik atas kondisi objektif keindonesiaan.

Penelitian ini dilandasi oleh beragam teori bahasa fungsional. Kajian bahasa saat ini tidak bersifat tunggal berdasar struktur internal, tetapi bahasa beririsan (cross-dimention) dengan ilmu lain yang menjadikan bahasa sebagai media komunikasi. Bahasa dalam posisi ini dipandang sebagai penghela ilmu pengetahuan. Arti penting fakta ini bagi ilmu bahasa adalah bahwa bahasa menjadi jendela untuk mengkaji realitas sosial atau peristiwa yang terjadi (Chaika, 1982; Badara, 2012). Melalui penggunaan bahasa kita dapat menafsirkan berbagai kenyataan sosial atau peristiwa, mengingat dalam posisi ini bahasa dapat dipandang sebagai representasi dari realitas atu peristiwa tersebut (Brown dan Yule, 1996:28).

Wacana merupakan data teks yang utuh dan menjadi kekayaan yang berharga dalam lapangan ilmu sosiologi, antropologi, psikologi, ilmu politik, dan ilmu sejarah(Heracleous, 2006:1; Hung Ng dan Bradac, 1993: 1). Oleh karena itu, para ahli memandang bahwa analisis wacana merupakan ilmu lintas bidang, mengingat seorang analisis wacana harus memiliki penguasaan ilmu-ilmu lain sesuai jenis teks yang dianalisis. Dalam wacana, ide kekuasaan sering disebut juga ideologi (Hung Ng dan Bradac, 1993: 3). Dalam pandangan Hodge dan Kress (1993:15) ideologi merupakan presentasi dari kenyataan yang diorganisasi secara sistematis.

Menurut Fairclough (2003: 129) setidaknya terdapat dua perbedaan karakter wacana dibandingkan dengan teks, yaitu (1) merepresentasi bagian bagian yang terpisah dari dunia dan (2) merepresentasi sebagian perspektif (cara pandang). Konsekuensinya, seorang analis wacana harus melakukan: (1) analisis terhadap bagian penting dalam dunia ini (termasuk kehidupan sosial) yang direpsentasikan, melalui pencarian tema-tema penting dan (2) mengindentifikasi bagian perspektif atau pandangan dari hal yang direpresentasikan. Referensi dalam wacana tidak hanya dapat dipahami dengan mengetahui makna sebuah tuturan teks, tetapi juga dengan memahami bagaimana makna tuturan berkontribusi terhadap dunia sosial yang membentuk identitas kita (Schiffrin, 2006:131). 
Kajian tentang identitas mulai banyak dilakukan seiring dengan kesadaran bahwa realitas perbedaan tidak selalu berkontribusi positif bagi pengembangan sosial. Wacana dapat menggambarkan situasi dan cara menampilkan identitas (Gee,1999: 38). Realitas identitas juga dapat bermakna negatif apabila dikontrusi tidak benar dalam konteks sosial. Identitas berkait dengan jatidiri seseorang atau kelompok manusia (KBBI, 2008: 517). Penelitian tentang identitas pernah dilakukan Mulyana (2001:229) terhadap orang Indonesia yang bermukim di Australia. Hasil penelitiannya menunjukkan bahwa terdapat orang Indonesia yang beridentitas religius, moderat, kosmopolitan, dan nasionalis. Penelitian Georgakopoulou (2006:83) dan Schiffrin (2006:103) menunjukkan bahwa melalui percakapan (conversation) dan naratif dapat diketahui konstruksi identitas penuturnya.

Dengan pemahaman bahwa berkomunikasi adalah kegiatan berwacana dan wacana direalisasikan dalam teks, tugas pendidikan bahasa menjadi lebih jelas. Pendidikan bahasa bertugas mengembangkan kemampuan memahami dan menciptakan teks karena komunikasi terjadi dalam teks atau pada tataran teks. Kemampuan berkomunikasi dalam memahami teks ini hendaknya didasarkan pada pendekatan, metode, dan teknik yang relevan agar tujuan komunikasi dan penggunaan wacana sesuai dengan tujuan berbahasa.

\section{METODE}

Penelitian ini merupakan penelitian kualitatif dengan pendekatan kritis (Muhadjir, 2000; Mulyana, 2001;Moleong, 2002).Data penelitian ini berupa data kualitatif, yakni wacana tertulis dalam buku teks tematik sekolah dasar (SD) kelas 1 yang diterbitkan Kemdikbud pada 2013. Data diolah melalui penggunaan analisis isi melalui penggunaan kata dan unsur kalimat (tata bahasa).
Tema yang dianalisis adalah Diriku (Assagaf dkk., 2013a)dengan subtema Teman Baru, Tubuhku, Aku Merawat Tubuhku, Aku Istimewa; tema Kegemaranku (Assagaf dkk., 2013b)dengan subtema Gemar Olahraga, Gemar Menyanyi dan Menari, Gemar Menggambar, dan Gemar Membaca; tema Kegiatanku (Assagaf dkk., 2013c)dengan subtema Kegiatan di Pagi Hari, Kegiatan di Siang Hari, Kegiatan di Sore Hari Kegiatan di Malam Hari; dan tema Keluargaku (Assagaf dkk., 2013d)dengan subtema Anggota Keluarga, Kegiatan Keluarga, Keluarga Besarku, dan Kebersamaan dalam Keluarga (Assagaf dkk., 2013).Penentuan tema ini menjadi faktor penting bagi pembelajaran bahasa Indonesia terutama dalam menentukan informasi apa yang hendaknya dikuasai oleh siswa (Anshori, 2010).

Data yang terkumpul dianalisis melalui langkah-langkah: seleksi data, data yang terkumpul diseleksi berdasarkan tujuan penelitian; identifikasi data, identifikasi mencocokkan data dengan teori yang digunakan; menyusun kartu data, pada tahap ini data yang sudah terkumpul dikelompokkan berdasarkan kartu data yang sudah disiapkan; analisis data, pada tahap ini peneliti menganalisis data-data yang telah diseleksi dan diidentifikasi berdasarkan teori; dan deskripsi data, data dideskripsikan berdasarkan kelompok data dan teori yang digunakan.

\section{HASIL PENELITIAN DAN PEMBAHASAN}

\section{GambaranIdentitas Budaya Keindonesian}

Tema 1, Diriku, berkaitan dengan pengenalan diri siswa sebagai siswa baru yang memiliki teman baru. Teks yang dikemukakan sangat pendek sesuai dengan tingkat literasi siswa kelas 1 SD.

(1) Di sekolah banyak teman. Kita
membutubkan teman. Kita senang
mempunyai teman.


Identitas yang dapat digambarkan melalui teks (1) adalah bahwa setiap peserta didik akan mendapatkan banyak teman di sekolah. Dia membutuhkan teman dan akan senang mempunyai teman. Ketiga rangkaian kalimat tunggal ini hendak menggambarkan bahwa sebagai manusia, anak membutuhkan kehidupan sosial, membutuhkan sesama (teman). Identitas manusia Indonesia sebagai makhluk sosial yang tidak dapat hidup tanpa manusia lainnya.Namun, teman sesungguhnya didapatkan dan dibutuhkan tidak hanya di sekolah, tetapi juga di tempat tinggal (rumah). Kata "membutuhkan" dan "senang" menggambarkan naluri alamiah manusia sebagai makhluk sosial. Manusia sebaiknya tidak merasa "dibutuhkan" dan "membenci" teman. Kalimat aktif ini menunjukkan bahwa harus ada upaya dari seseorang (peserta didik) untuk memperoleh teman atau teman itu akan diperoleh apabila ada upaya dari seseorang untuk berteman.

Pada tema 1 nama-nama peserta didik yang diperkenalkan merepresentasi sebagian etnis (suku) yang ada di Indonesia. Nama Udin, Siti, Beni, Dayu, Edo, dan Lani menggambarkan darimana mereka berasal. Nama-nama ini dikuatkan dengan gambar peserta didik sesuai dengan identitas yang dimilikinya. Misalnya, nama Siti digambarkan sebagai anak berkerudung sedangkan Edo digambarkan sebagai anak berambut keriting. Hal ini menunjukkan bahwa peserta didik akan memperoleh teman yang berbeda dan harus dapat berteman dengan teman yang berbeda. Teks dan gambar ini menunjukkan keberagaman yang harus dikenali dan dipahami peserta didik sejak dini.

Teks lain yang menggambarkan identitas keindonesiaan terdapat dalam rangkaian kalimat berikut.

(2) Kita bergembira.Tubub kita banyak manfaatnya.Kita bersyukur kepada Tuban.

Teks (2) berkaitan dengan perkenalan tentang tubuh. Peserta didik diperkenalkan dengan identitas diri yang mereka punya dan manfaat dari anggota tubuh. Anggota tubuh yang kita punya merupakan pemberian Tuhan sehingga kita harus mensyukurinya. Kata "kita" berarti semua manusia (termasuk peserta didik) memiliki kewajiban bersyukur kepada Tuhan. Tiga penggalan kalimat tersebut menggambarkan bahwa manusia Indonesia bukan manusia pragmatik, yang hanya melihat kebermanfaatan sesuatu, tetapi manusia spiritualis (religius) yang memahami keberadaan tubuh, manfaat tubuh, dan menggunakan tubuh sesuai dengan kehendak Tuhan yang memberikannya. Itulah makna bersyukur dalam konteks kalimat di atas. Nilai religius ini dimiliki oleh seluruh bangsa Indonesia, sekalipun dari sudut pandang agama yang berbeda-beda.

\section{(3) Setiap anak istimewa. Kita berbeda tetapi saling menyayangi.}

Teks (3) menunjukkan identitas keberagaman yang ada pada diri anak tetapi nilai-nilai humanisme tetap ditunjukkan. Frasa "saling menyayangi" menunjukkan pesan nilai humanisme yang tengah dipertunjukkan dalam teks tersebut. Keistimewaan anak berada pada masingmasing kelebihannya, baik secara fisik maupun kemampuan. Teks ini hendak mengikat anak-anak bukan dari aspek kekurangannya, teks ini justru menampilkan kelebihan anak sebagai sebuah keistimewaan. Logika yang dikembangkan dalam teks ini memicu anak untuk saling menghargai atas potensi masing-masing. Dalam konteks lain teks di atas dapat dipahami bahwa perbedaan merupakan sebuah keistimewaan. Perbedaan yang digambarkan dalam teks (3) diperjelas dengan uraian teks (4), teks (5), teks (6), teks (7), teks (8) dan teks (9).

(4) Udin dapat berlari cepat. Edo dapat berlari lebih cepat. Udin tidak kecewa.Karena semua anak istimewa.

Pada teks (4) perbedaan yang dieskplorasi dan disajikan adalah persoalan kemampuan berlari. Perbedaan kemampuan berlari merupakan sebuah keistimewaan bukan kekurangan. Peserta 
didik akan dihadapkan pada realitas yang harus dipahami sejak dini dengan baik bahwa perbedaan akan senantiasa ada dan merupakan keistimewaan yang tidak perlu dikecewakan.

(5) Aku tinggal di kampung. Temanku

banyak.Temanku tinggal di

gunung.Udaranya segar.

Temanku tinggal di

pantai.Pemandangannya indah.Temanku

tinggal di kota.

Gedung-gedungnya tinggi.Kami semua bahagia.

Demikian pula, pada teks (5) perbedaan tempat tinggal dengan segala ciri khasnya merupakan sebuah kenyataan yang dihadapi anak. Kampung dengan gambaran pegunungan dan segar merupakan kenyataan. Demikian pula ada anak yang berasal dari pantai dengan pemandangan yang indah. Selain itu ada anak yang berasal dari kota dengan gedung-gedung yang tinggi. Semua tempat tinggal tersebut hendaknya dinikmati oleh setiap anak dengan kebahagiaan. Berbeda tempat tinggal merupakan keistimewan dan harus dirasakan dengan penuh bahagia.

(6) Edo suka buah jeruk. Udin suka buah apel.Siti suke buah mangga.

Buab pemberian Tuban.Kita bersynkur kepada Tuhan.

Perbedaan juga dicontohkan dalam teks (6) dengan kesukaan makan buahbuahan, ada yang suka jeruk, apel, atau mangga. Buah-buahan tersebut apabila dipahami dari sikap religius merupakan pemberian Tuhan. Oleh karena itu, setiap makanan yang diperoleh harus disyukuri. Dengan kata lain, teks ini hendak menjelaskan bahwa perbedaan itu merupakan anugrah Tuhan yang harus disyukuri. Mensyukuri perbedaan inilah yang harus mulai dijelaskan kepada peserta didik sejak dini karena sikap ini merupakan embrio lahirnya toleransi dalam kehidupan sosial.

(7) Setiap orang memiliki kelebihan.Semuanya tolong-menolong.

Pada teks (7) dijelaskan bahwa perbedaan merupakan kelebihan yang hendaknya dipahami sebagai instrumen untuk berbuat baik (tolong-menolong) kepada pihak lain. Kelebihan merupakan potensi yang dimiliki seseorang agar dengan dengan kelebihan tersebut seseorang dapat menolong sesamanya. Karena setiap orang memiliki kelebihan maka siapa pun dapat menolong sesamanya.

(8) Laki-laki dan perempuan adalah ciptaan Tuhan.Semua bekerja sama.

Perbedaan berikutnya yang digambarkan teks (8) adalah jenis kelamin yang juga sudah ditetapkan Tuhan. Perbedaan jenis kelamin ini pun merupakan keistimewaan yang harus disyukuri. Jenis kelamin bukan instrumen untuk membedakan manusia, melainkan instrumen untuk bekerja sama. Keistimewaan menjadi media untuk bekerja sama karena potensi yang dimiliki berbeda-beda.

\section{(9) Namaku dan teman-temanku berbeda.Semua nama bagus.}

Demikian pula, nama-nama yang diperkenalkan pada awal tema ini. Perbedaan nama merupakan keistimewaan dan semua nama baik sesuai dengan budaya masing-masing anak. Di sini peserta didik dipahamkan pada satu kenyataan yang harus disikapi dengan benar. Nama tidak boleh diolok-olokan, tetapi sebaliknya memahami perbedaan nama untuk saling memuji satu sama lainnya. Teks dalam tema 1 ini memperkenalkan keragaman justru dari nama, yaitu Udin, Siti, Beni, Dayu, Edo, dan Lani. Nama-nama ini merepresentasi satu suku/etnis tertentu di Indonesia, misalnya Udin merupakan nama yang banyak digunakan pada etnis Sunda. Perbedaan dalam konteks Indonesia menjadi kenyataan yang tak bisa terhindarkan, dan peserta didik sebagai bagian dari bangsa ini hendaknya 
dipahamkan pada kenyataan yang berbeda ini sehingga muncul sikap saling menghormati dalam perbedaan yang ada.

Tema 2 buku ini adalah kegemaranku dengan subtema: gemar olahraga, gemar menari dan menyanyi, gemar menggambar, dan gemar membaca.Peserta didik menjumpai materi sikap tercermin pada teks (1) berikut ini.

(1) Beni selesai bermain bola.Badan Beni berkeringat.Beni melepas sepatu bolanya. Sepatu diletakkan di rak sepatu.Beni membuka kaos olahraganya.

Kaos dimasukkean ke dalam

keranjang.Setelah itu Beni mandi.

Sikap yang digambarkan pada teks (1) lebih berupa sikap atau prilaku yang harus dilakukan secara individual. Sikap dan prilaku tertib hendak dipahamkan kepada anak melalui tokoh Beni.

(2) Siti suka olahraga bulu tangkis. Lani juga suka olabraga bulu tangkis.

Main bulu tangkis bisa satu lawan satu.Bisa juga berpasangan.

Teks (2) merepresentasi pengetahuan daripada sikap atau keterampilan, bahwa bulu tangkis dapat dilakukan dengan cara satu lawan satu atau berpasangan. Teks dengan makna sejenis terdapat pada teks (3) berikut.

(3) Udin suka olahraga sepak bola.Tim sepak. bola terdiri atas sebelas pemain.Satu orang sebagai penjaga gawang.Mereka harus bekerja sama. Memasukekan bola ke gawang lawan.

Teks (4) yang hendak dijelaskan dalam tema ini merupakan doktrin tentang fungsi olahraga. Tetapi teks menggambarkan identitas peserta didik Indonesia yang harus gemar berolahraga, karena akan membuat tubuh menjadi sehat, jantung kuat, dan paru-paru kuat.

(4) Olabraga penting untuk tubub kita. Olahraga membuat tubuh kita sehat.
Olahraga membuat jantung kita kuat.Olahraga membuat paru-paru kita kuat.

Namun demikian, identitas keindonesian berikutnya tergambar pada kutipan teks (5).

(5) Kesehatan adalah karunia Tuban.Kita harus menyukurinya.

Dua penggal kalimat tersebut hendak menekankan bahwa sebagai manusia Indonesia, peserta didik harus memahami bahwa melalui olahraga tubuh menjadi sehat, namun kesehatan merupakan karunia Tuhan dan kita harus mensyukurinya. Sikap religius ini hendak dipahamkan kepada peserta didik dalam wacana kegemaran berolahraga.

Teks (6) menunjukkan gambaran identitas keindonesian berupa disiplin.

(6) Siti dan Lani gemar bermain bulu tangkis.Siti dan Lani rajin berlatih.Pak Tagor melatih Siti dan Lani.Pak Tagor mengajarkan aturan dan sikeap yang baik. Siti dan Lani menaatinya.

Identitas disiplin hendak ditekankan pada teks ini. Melalui berolahraga, setiap peserta didik diperkenalkan pada aturan yang harus dilaksanakan atau ditaati. Olahraga dengan kata lain merupakan instrumen untuk melatih kedisiplinan dan ketaatan pada aturan. Keataan pada aturan inilah yang sering disebut sebagai sikap sportif. Teks di atas ditegaskan kembali dalam teks (7) berikut ini.

(7) Kita harus menghormati orang lain dalam berolahraga.Kita harus menaati peraturan. Kita harus menjaga sopan santun.

Teks (7) merupakan kesimpulan yang hendak ditegaskan dalam teks olahraga. Pesan moral yang hendak ditegaskan adalah menghormati orang lain, menaati peraturan dan menjaga sopan santun. Tiga pernyataan sikap sosial inilah yang hendak ditegaskan pada tema ini. Identitas yang hendak disampaikan melalui teks ini, bahwa peserta didik harus 
memiliki sikap sosial sekalipun dalam berolahraga.

(8) Setiap orang memiliki kegemaran masingmasing.Kita harus menghargai perbedaan tersebut.

Perbedaan menjadi realitas dalam segala aspek kehidupan yang harus diperkenalkan kepada peserta didik, termasuk kegemaran. Identitas yang hendak ditekankan pada teks (8) di atas adalah sikap menghargai perbedaan atas kegemaran yang berbeda-beda.

(9) Saat bernyanyi kita mengeluarkan suara. Ada suara lembut seperti suara orang berbisik.

Ada suara sedang seperti orang

berbicara.Ada suara keras seperti orang berteriak.

Perbedaan juga digambarkan pada teks (9) pada saat kita bernyanyi. Suarasuara itu bermacam-macam.

(10) Indonesia kaya akan budaya.Salah satunya adalah tarian daerah.Setiap daerah memiliki tarian yang indah.

(11) Indonesia memiliki banyak suku. Indonesia memiliki banyak lagu daerah.

Lagu daerah kita bagus bagus.Kita harus memeliharanya.

Puncaknya, perbedaan itu tercermin dalam budaya yang terdapat di daerahdaerah di Indonesia. Budaya tersebut dapat berbentuk tarian daerah yang indah. Budaya daerah yang beragam tersebut harus dipelihara agar tetap lestari.Teks di atas juga memperkenalkan kekayaan budaya yang dimiliki Indoneia, baik suku bangsa maupun lagu daerah. Kekayaan budaya ini merupakan potensi besar bangsa ini yang harus disadari sejak dini. Identitas keindonesiaan inilah yang harus diperkenalkan kepada peserta didik sehingga mereka menjadi pribadi yang sadar akan perbedaan ini.

Tema 3 buku ini adalah kegiatanku. Tema ini dibagi atas subtema kegiatan di pagi hari, siang hari, sore hari dan malam hari. Identitas keindonesian dalam tema ini digambarkan berikut ini.
(1) Matahari terbit pada pagi hari.Cahayanya bersinar terang. Udara pun menjadi hangat. Semua terlihat jelas. Hatiku menjadi riang.Terima kasib Tuhan.Atas karunia yang Kauberi.

Identitas manusia reigius tercermin dalam teks di atas. Pada bagian awal tema ini peserta didik diajak memaham alam dan makhluk lain ciptaan Tuhan, yaitu matahari. Cahaya yang dipancarkan matahari seharunya melahirkan ras syukur kita kepada Tuhan karena cahaya matahari tersebut merupakan karunia. Identitas manusia religius ini mengawali penjelasan tema kegiatanku. Identitas religius juga terdapat secara eksplisit pada teks berikut.

(2) Sebelum berangkeat sekolah. Siti selalu sarapan.Siti sarapan dengan menu yang sehat.

Sarapan membuat tubuh Siti kuat.Sebelum makan Siti berdoa.Siti makan secukupnya. Setelah makan Siti juga berdoa.

Makan dimaknai bukan hanya memenuhi kebutuhan fisik supaya sehat, tetapi juga merupakan kegiatan ritual sehingga harus dimulai dengan doa. Berdoa dilakukan sebagai cermin sikap syukur atas rezeki yang diberikan Tuhan kepada kita sehingga makanan yang dimakan dapat menyehatkan tubuh.

(3) Pelajaran telab usai.Semua siswa memberi salam kepada ibu guru. Siwa petugas piket belum pulang.Mereka membersibkan kelas lebih dulu.Edo menyapu lantai.Siti membersibkan meja.Udin menghapus papan tulis.Dayu merapikan buku dan kertas.Lani mengurus tanaman.Kelas menjadi bersib dan rapi.Kelas yang bersib indah dipandang.

Teks (3) menggambarkan identitas religius dan identitas manusia yang mencintai kesehatan dan keindahan. Identitas ini diperankan melalui tokoh cerita buku ini dalam beragam aktivitas. Para tokoh juga merupakan gambaran dari keanekaragaman manusia Indonesia baik etnis maupun agama. Cermati prilaku religius dan prilaku sehat yang dilakukan tokoh Siti dalam teks (4), (5), (6) berikut. 
(4) Siti makan siang di rumah.Sebelum makan Siti mencuci tangan dan berdoa. Siti bersyukur kepada Tuban. Siti makan siang dengan menu sehat.

(5) Pulang sekolah Lani beristirahat.Tidur siang banyak manfaatnya.Tidur siang membuat tubuh sehat. Setelah tidur siang badan terasa segar.Belajar dan bermain lebih semangat.

(6) Udin suka mendengarkan cerita.Setiap malam Udin dibacakan buku cerita. Ayah dan ibu bergantianmembacakan cerita.Malam ini ayah membacakan cerita. Udin merasa senang sekali.Udin berterima kasib kepada ayah. Ayah berpesan kepada Udin untuk berdoa sebelum tidur. Ayah mematikan lampu kamar.

Beberapa identitas religius yang digambarkan dalam teks di atas adalah bersyukur kepada Tuhan, berdoa sebelum makan, berterima kasih, dan berdoa sebelum tidur. Sementara itu prilaku disiplin dan tertib diungkapkan dalam bentuk makan siang dengan menu sehat, mencuci tangan, tidur siang, dan belajar dan bermain.

Tema 4 bertajuk keluargaku, terdiri atas subtema anggota keluarga, kegiatan keluarga, keluarga besarku, dan kebersamaan dalam keluarga. Identitas keindonesiaan digambarkan dalam teks sebagai berikut.

(1) Dalam keluarga Udin ada ayah dan ibu. Ada kakak dan Udin.Keluarga Udin saling menyayangi.

Keluarga yang digambarkan pada teks (1) merupakan keluarga yang utuh, yakni ada ayah, ibu, kakak, dan Udin serta di antara mereka memiliki rasa saling kasih sayang.

(2) Keluarga adalab karunia Tuban.Aku menyayangi keluargaku.

Keluarga dipahami bukan hanya sebagai sekumpulan anak manusia yang terikat dalam hubungan biologis (ayah, ibu, dan anak), tetapi juga keluarga terbentuk karena karunia Tuhan. Oleh karena itu, keluarga dibentuk berdasarkan kasih sayang. Seorang anggota keluarga harus menyayangi keluarganya. Kasih sayang menjadi modal dasar dalam pembentukan keluarga yang utuh. Identitas keindonesiaan yang tercermin dari kedua teks di atas adalah bahwa orang Indonesia adalah manusia yang berakar pada kasih saya dalam kehidupan keluarga.

(3) Anggota keluarga memiliki kegiatan yangberbeda-beda.Pada sore hari ayah membaca koran.Ibu mendampingi Udin menggambar. Kakak sedang belajar.

Pada teks (3) anggota keluarga memiliki peran yang berbeda-beda. Peran itu menunjukkan tanggung jawab yang dimiliki angggota keluarga. Belajar, menggambar, mendampingi, atau membaca merupakan peran atau kegiatan yang biasa dilakukan dalam keluarga. Semua kegiatan tersebut bermakna positif bagi terbentuknya keluarga yang saling menyayangi.

(4) Kita ingin selurub keluarga sehat.Kita semua harus rajin berolahraga.Senam irama asyik dan menyebatkan. Apalagi jika dilakukan bersama keluarga.Mari melakukan senam irama.

Kegiatan keluarga yang ditampilkan juga beragam, misalnya berolahraga bersama. Kebersamaan menjadi modal utama keluarga selain kasih sayang. Pesan ini penting diberikan mengingat kesibukan anggota keluarga saat ini memungkinkan sulitnya terbangun kebersamaan dalam keluarga. Padahal kebersamaan dalam keluarga merupakan instrumen lahirnya kasih sayang dalam keluarga. Teks (4) di atas memberikan pesan pentingnya agenda bersama dalam keluarga.

(5) Setiap keluarga memiliki peraturan.Contohnya pembagian tugas merapikan rumah

Patuh dan tertib akan membuat lebih teratur.

Keluarga juga dibangun dalam aturan yang berlaku dalam anggota keluarga. Aturan tersebut akan tegak apabila seluruh anggota keluarga menjalankan setiap aturan yang disepakati. Peraturan itu dapat berbentuk tugas-tugas masing-masing anggota keluarga yang harus dijalankan. Keluarga sebagai 
miniatur bangsa menentukan kehidupan masyarakat yang lebih luas. Keluarga menjadi cermin seseorang dalam masyarakat, apabila keluarganya utuh dan disiplin, maka dia akan bermasyarakat dengan baik. Demikian pula sebaliknya. Pada teks (6) dan (8) pembagian tugas tersebut diuraikan lebih terperinci.

(6) Ibu hendak menyiapkan makan.Udin dan

Mutiara membantu ibu menata meja makan.

Udin menyiapkan piring sendok dan garpu.Mutiara mengisi gelas dengan air minum.

Bekerja sama membuat pekerjaan menjadi ringan. Apakah kamu suka membantu ibu?

(7) Dalam keluargaku ada ayah dan ibu.Ada juga kakak. Aku menyayangi ayah dan ibuku.

Aku menghormati ayah dan ibuku. Aku menyayangikakakeku.

Keluarga akan utuh terbangun dalam fondasi kasih sayang dan saling menghormati. Identitas berkeluarga ini merupakan komponen kehidupan bernegara yang harus dipertahankan oleh bangsa Indonesia dan dipahamkan sejak dini kepada peserta didik. Melalui teks ini penulis ingin menekankan peran yang dimiliki dan dilakukan oleh peserta didik dalam keluarganya. Hal penting lain yang ditanamkan adalah bahwa bersyukur harus dilakukan dalam kegembiraan bukan keterpaksaan. Melalui peran-peran berkeluarga inilah, pada akhirnya setiap orang memperoleh makna hidup (spiritual) dalam mensyukuri nikmat Tuhan. Berkeluarga dapat dipahami sebagai nikmat Tuhan yang harus disyukuri. Sama halnya dengan memiliki keluarga merupakan nikmat Tuhan yang harus disyukuri dalam bentuk saling menghormati dan menyayangi (lihat teks [8] dan [9]).

(8) Edo menonton televisi bersama Ayah dan

Ibu.Edo menonton sambil dipeluk. Ibu.

Edo senang dipeluk. Ibu.Edo sangat sayang

kepada Ayah dan Ibu.Kita harus

bersyukur.

Kita mempunyai orang tua yang menyayangi kita.
(9) Ayah ibu telah berjasa kepada kita.Tak ada yang menyayangi kita seperti ayah ibu. Kita barus patuh kepada ayah ibu.Kita menyayangi ayah ibu. Ayah ibu selalu menjaga kita setiap saat.

Kebersamaan keluarga dapat diperankan dalam berbagai kegiatan sosial secara bersama-sama. Teks (10), (11), dan (12) merupakan realisasi dari peran-peran yang dapat dilaksanakan dalam membangun kerjasama. Peran-peran ini sering kita lakukan dalam kehidupan sosial, terutama pada saat kegiatan hari-hari besar yang memungkinkan keluarga dapat berperan aktif secara bersama-sama. Teks ini mengajarkan kepada anak-anak tentang makna kebersamaan dalam berkeluarga sehingga kehadiran mereka bukan saja menjadi pelengkap dalam keluarga, namun memiliki makna yang tak terpisahkan dari kehadiran keluarga tersebut. Teks ini juga menunjukkan karakteristik keluarga yang ideal yang harus ada di masing-masing rumah dengan menekankan pada peran anak yang potensial dalam membantu mendorong terciptanya keluarga yang ideal tersebut.

(10) Kita senang berlomba.Menang atau kalah tak apa apa. Asalkan kita sudab berusaha. Jika kalah tidak perlu kecewa. Saat bermain bersama.Sangat penting bekerja sama. Agar dapat meraih kemenangan.

(11) Siti anak yang baik. Siti suka membantu ibu.Siti juga suka membantu ayah dan saudara.

Anak yang suka membantu disayang Tuban.

(12) Udin dan keluarga berlomba tarik tambang.Mereka berlomba untuk. memperingati Hari Kemerdekaan.Lomba tarik tambang membutubkan kesungguban.Lomba tarik tambang membutubkan kerja sama.Udin dan keluarga memenangkan lomba. Keluarga Udin saling mendukung.Keluarga Udin saling bekerja sama.

Pada tema 4 ini fokus pembentukan sikap terdapat pada aktivitas keluarga. Anak diajak memahami peran 
mereka dalam keluarga dan diharapkan dapat mendorong terbangunnya keluarga sesuai uraian teks. Dengan mengamati formula bahasa (jenis tuturan) banyak pernyataan yang bersifat ilokusi dan perlokusi, artinya pernyataan tersebut memungkinkan dan mengharuskan ditindaklanjuti dalam bentuk perbuatan dan prilaku, baik oleh anak maupun oleh angggota keluarga lain. Secara ideologis, kita memahami bahwa keutuhan kita berbangsa dan bernegara sangat ditentukan oleh keharmonisan dalam keluarga. Dengan demikian, tema ini menjadi sangat urgen dan sinergis dengan tantangan kehidupan modern yang akan dihadapi bangsa ini.

\section{Penggunaan Bahasa Sebagai Representasi Identitas Budaya Keindonesiaan}

Penggunaan bahasa yang dimaksudkan dalam bagian ini terdiri atas kata, frasa, dan kalimat yang mencerminkan atau merepresentasi identitas keindonesian. Kata, frasa, dan kalimat dipandang sebagai medium yang dapat mewakili pesan dari penutur sebuah bahasa atau peristiwa yang hendak diwakilinya. Dengan menganut teori ini penelitian ini mengidentifikasi penggunaan kata, frasa, dan kalimat untuk mengetahui identitas keindonesiaan apakah yang hendak digambarkan dalam buku teks sekolah dasar.

Penggunaan bahasa pada tema 1 lebih banyak didominasi istilah-istilah yang berkaitan dengan tema: Diriku. Kata, frasa, dan struktur kalimat yang diperkenalkan masih sangat sederhana, umumnya menggunakan kalimat tunggal. Kalimatkalimat tunggal tersebut dirangkai menjadi paragraf dan wacana sederhana sehingga memberikan pesan yang kuat bagi peserta didik.Teks berikut menunjukkan repetisi objek: Di sekolah banyak teman.Kita membutubkan teman.Kita senang mempunyai teman.Diksi "teman" diulang pada tiga kalimat tersebut, berarti penulis hendak menekankan arti pentingnya keberadaan teman kepada peserta didik. Mengapa teman demikian penting bagi peserta didik? Pertanyaan ini menjadi ideologi penulisan buku teks, yakni bahwa setiap manusia harus hidup dalam komunitas sosialnya dan keberartian manusia adalah ketika memiliki komunitasnya.

Kata yang digunakan mencakup kata pengganti diri, yaitu kita, banyak teman, anak istimewa, nama bagus, laki-laki, perempuan, dan nama peserta didik. Kata kita menunjukkan kolektivitas yang hendak dibangun dalam teks tersebut yang bermakna semua orang. Frasa banyak teman merupakan kondisi yang harus dimiliki peserta didik. Semakin banyak teman, peserta didik akan terpenuhi kebutuhan dan kesenangannya. Frasa anak istimewa merujuk pada sebutan bagi seluruh anak dengan masing-masing kemampuannya. Setiap anak berbeda kemampuan dan perbedaan tersebut disebut sebagai keistimewaan. Kata istimewa merupakan konsep yang harus dikembangkan dalam konteks perbedaan kondisi dalam diri anak dan untuk menanamkan sikap percaya diri akan potensinya. Jenis kelamin laki-laki dan perempuan diperkenalkan dalam buku ini untuk menggambarkan dua jenis manusia yang berbeda. Perbedaan yang harus dipahami anak bermula dari perbedaan nama dan kondisi fisik mereka.

Teks juga dibangun melalui penggunaan kata kerja yang dikontruksi untuk kepentingan penanaman nilai dan sikap. Kata kerja tersebut meliputi membutubkan, mempunyai, bersyukur, menyayangi, berlari, tinggal, suka, pemberian, dan tolong-menolong. Kata kerja ini dari aspek pilihan kata mendukung makna yang hendak dibangun dalam teks. Pemaknaan kosakata kerja tersebut bersifat gramatikal dan kontekstual. Namun, semua kosakata kerja mengarah pada dukungan ideologi teks.

Kosakata dalam tema 1 juga mengandung diksi berfungsi sifat dan keterangan. Kosakata tersebut umumnya merupakan perincian dari subjek, predikat atau objek yang disebutkan pada kalimat 
tersebut. Frasa lebih cepat, tidak kecewa, di kampung, di gunung, udaranya segar, di pantai, pemandangannya indah, di kota, gedungnya tingitinggi, bekerja sama, berbeda, dan nama bagus merupakan frasa yang berfungsi sebagai keterangan. Frasa tersebut digunakan untuk memberikan perincian pada tempat atau benda yang dijelaskan di awal. Frasa keterangan ini juga ditulis dalam rangka memberikan penegasan atas perbedaan yang diungkapkan dalam teks tersebut, sekalipun pada akhir teks dijelaskan kalimat resolusi sebagai pesan utama teks.

Melalui penggambaran bentuk lingual di atas, penelitian ini dapat menemukan korelasi antara bentuk lingual dengan pemaknaan identitas budaya atau berpretensi identitas. Frasa membutubkan teman atau memiliki teman mereferensi pada identitas sosial, karena pertemanan merupakan bentuk sosialisasi manusia. Sebagai makluk sosial, eksistensi manusia sangat ditentukan oleh kuantitas dan kualitas pertemanannya. Bahkan pemaknaan dan nilai hidup manusia sangat ditentukan oleh jumlah dan keluasan pertemanannya. Dalam masyarakat Indonesia berlaku pepatah: seribu teman masih kurang, satu musuh masih terlalu banyak.

Kata bersyukur dan Tuban apalagi bila dirangkai dalam kalimat Kita bersyukur kepada Tuhan merujuk pada identitas religius.Identitas ini menunjukkan bahwa bangsa Indonesia, khususnya pelajar Indonesia harus menyadari bahwa hubungan yang dijalin bukan hanya dengan sesama (manusia), tetapi manusia harus memiliki komunikasi dengan Tuhan (spiritual). Identitas religius ditekankan dalam teks ini sesuai dengan tujuan pendidikan nasional dalam rangka mencetak manusia Indonesia yang beriman dan bertakwa kepada Tuhan Yang Mahaesa. Sikap religius ini didasarkan pada pelaksanaan ajaran agama, yaiut bersyukur. Melalui teks tersebut, peserta didik diharapkan menjadi pribadi yang pandai bersyukur.
Kalimat Setiap anak istimewa merujuk pada identitas percaya diri dan optimis atas potensi yang dimiliki. Sikap ini akan membangun kemandirian dan kepercayaan diri yang baik dalam menjalani hidup dengan berpandu pada potensi diri. Memandang perbedaan (potensi, fisik, kompetensi) sebagai keistimewaan berimplikasi bahwa setiap anak akan berkontribusi sesuai dengan keistimewaan yang dimilikinya. Sementara ini, perbedaan kemampuan hanya dipandang sebagai perbedaan semata dan dampak dari kompetensi atau persaingan. Konsep ini harus diubah dengan kerjasama (networking) sehingga tujuan mendidik anak bukan melahirkan pribadi yang kompetitif dan berdaya saing, melainkan menjadi pribadi yang mampu bekerjasama dengan dunia di luar dirinya.

Sementara itu kalimat Kita berbeda tetapi saling menyayangi menunjukkan identitas toleransi atas perbedaan yang menjadi realitas dalam kehidupan sosial. Kata berbeda memberikan referensi adanya kompleksitas sosial yang heterogen. Fakta ini harus disikapi setiap individu agar perbedaan tidak menjadi bencana dan sumber konflik. Pengakuan terhadap realitas perbedaan ini penting karena akan memberikan cara pandang yang proporsional pada kehidupan sosial sehingga yang lahir adalah sikap kasih sayang terhadap sesama.

Perbedaan yang dicontohkan dalam teks buku ini (jenis kelamin, kesukaan, kemampuan, tempat tinggal, nama) akan tampak indah apabila dipandang sebagai sebuah realitas yang wajar dan arif. Kalimat Kami semua bahagia mengharapkan bahwa perbedaan menjadi kebaikan dan dilihat sebagai potensi kebahagiaan bagi umat manusia. Perbedaan juga sebuah kenyataan yang diberikan Tuhan dan harus disyukuri karena setiap manusia memiliki potensi yang berbedabeda.Perbedaan itu memiliki nilai sebagaimana digambarkan dalam dua kalimat berikut Laki-laki dan perempuan adalah ciptaan Tuban.Semua bekerja 
sama.Makna yang sama digambarkan dalam kalimat berikut Namaku dan teman-temanku berbeda. Semua nama bagus. Dengan demikian perbedaan yang terefleksi dalam bahasa dipahami sebagai sebuah media untuk membangun kerjasama yang sejajar dengan sesama manusia.

Pada tema 2 kosakata yang digunakan mengacu pada tema kegemaranku, yaitu olahraga, menari dan menyanyi, menggambar, dan membaca. Kosakata olahraga lebih banyak digunakan daripada kosakata menari dan menyanyi, menggambar, dan membaca. Namun, pola alur teks dituliskan melalui struktur yang sama. Kosakata utama yang digunakan dalam menggambarkan kegemaran dalam berolahraga meliputi bulu tangkis, sepakbola, tubuh, jantung, paru-paru, sehat, kuat, karunia Tuban, bersyukur, aturan, menaati, menghormati, dan sopan santun. Kosakata tersebut menggambarkan aktivitas olahraga (sepakbola dan bulutangkis) yang dilakukan tokoh dalam teks tersebut yang bermanfaat untuk kesehatan tubuh, jantung yang kuat dan paru-paru yang kuat.

Kosakata yang digunakan dalam teks ini mencakup kata benda, kata kerja, dan kata keterangan. Kata benda yang digunakan seperti Beni, bola, badan, rak sepatu, rak sepatu, kaos olahraga, keranjang, bulu tangkis, olabraga, sepakbola, penjaga gawang, tubub, jantung, paru-paru, kesehatan, Lani, Siti, Pak Tagor dan lain-lain. Sementara itu, kosakata yang berbentuk kata kerja adalah bermain, berkeringat, melepas, diletakean, mandi, suka, bersyukur dan lain-lain. Kata yang termasuk kata keterangan seperti satu lawan satu, berpasangan, sebelas pemain, bekerja sama, sopan santun, lembut dan lain-lain.

Gambaran identitas dalam bentuk lingual semakin jelas melalui analisis kalimat atau wacana. Kalimat Mereka harus bekerja sama menggambarkan bahwa dalam kegiatan olahraga, terutama olahraga yang diikuti secara tim ditentukan oleh kerjasama para pemainnya. Kalimat ini mengindikasikan identitas keindonesiaan yang harus ada dalam masyarakat Indonesia. Sebagai bagian dari anggota masyarakat, kehidupan sosial dan pembangunan bangsa Indonesia akan terlaksana apabila antarkomponen bangsa dapat bekerja sama dengan baik. Oleh karena itu, nilai kerjasama dalam pendidikan digambarkan oleh bidang olahraga yang bersifat universal.

Demikian pula, sikap sportif dan taat pada aturan dapat digambarkan dalam kalimat berikut: Kita harus menghormati orang lain dalam berolahraga dan Kita harus menaati peraturan sertaKita harus menjaga sopan santun.Kalimat tersebut sekalipun bersifat doktriner tetapi mengandung makna bahwa dalam kehidupan sosial terdapat tata aturan yang harus dipatuhi oleh semua warga negara. Pada saat yang sama, peserta didik harus saling menghormati pihak lain dan bersikap santun dalam melakukan interaksi sosial.

Kegemaran olahraga diberikan kepada para peserta didik melalui teks ini mengingat melalui olahraga peserta didik dalam diajari membangun toleransi. Kalimat Setiap orang memiliki kegemaran masing-masing danKita harus menghargai perbedaan tersebut merupakan perwujudan sikap toleransi dalam memahami perbedaan kegemaran. Peserta didik sejak dini diharapkan para realitas sosial yang dihadapinya, bahwa kegemaran tidak bermakna sama (tunggal) tetapi jamak dan kompleks.

Kekayaan bangsa ini bukan hanya terletak pada kegemaran olahraga, tetapi terdapat pada bidang kesenian dan budaya. Kalimat Indonesia kaya akan budaya merupakan kalimat informatif sekaligus menguatkan bahwa budaya kita merupakan kekayaan bangsa. Demikian pula kalimat Indonesia memiliki banyak suku dan Indonesia memiliki banyak lagu daerah merupakan perwujudan atas kekayaan budaya bangsa. Yang hendak diajarkan kepada peserta didik terdapat dalam kalimat kita harus memeliharanya. Hal ini merupakan sikap yang harus dimiliki setiap warga negara termasuk peserta didik. 
Penggunaan kosakata pada tema 3 terdiri berkaitan dengan subtema kegiatan di pagi hari, siang hari, sore hari dan malam hari. Kosakata-kosakata tersebut ada yang menggambarkan suasana dan kegiatan yang dilakukan peserta didik pada fase waktu tersebut. Kosakata yang menggambarkan suasana, yaitu matahari, pagi hari, cahaya, terang, udara, hangat, hatiku, riang dan lain-lain. Sementara itu, kosakata yang menggambarkan aktivitas meliputi sarapan, makan, berdoa, membersihkan, merapikan, dan lain-lain. Berdasarkan analisis, semua penggunaan kosakata bermuara pada identitas religius yang hendak dibangun penulis teks. Kata berdoa dan bersyukur dalam setiap fase aktivitas menunjukkan bahwa manusia Indonesia, termasuk peserta didik adalah pribadi yang menyandarkan kegiatan hidupnya kepada Tuhan.

Kosakata pada tema ini juga berupa kata benda seperti matahari, cahaya, udara, hatiku, karunia, sekolah, siti, sarapan, menu, sarapan, tubub, pelajaran, siswa, ibu guru, petugas piket, mereka, kelas, Edo, lantai, meja, udin, papan tulis, buku, kertas, dayu, lani, tanaman, kelas, menu sehat, tangan, sekolah, lani, tubuh, badan, udin, cerita, buku cerita, ayah, dan ibu. Sementara itu, kosakata berbentuk verbal terdapat pada kata terbit, bersinar, terlihat, terima kasih, berangkat, membuat, makan, berdoa, memberi, membersibkan, menghapus, merapikan, mengurus, menyapu, dipandang, makan, mencuci, bersyukur, pulang, tidur, beristirahat, bermain, belajar, suka, mendengarkan, dibacakan, bergantian, membacakan, berpesan, dan mematikan. Kedua jenis kata tersebut mendominasi penggunakan kosakata pada tema ini. Selain itu, terdapat kata sifat, keterangan dan konjungsi yang berfungsi sebagai penegas, penjelas, dan penghubung kosakata utama di atas.

Penggambaran identitas budaya keindonesian pada tema ini dilakukan melalui penggunaan kalimat dan wacana. Identitas religius misalnya digunakan dalam beberapa kalimat dan wacana misalnya pada saat menggambarkan suasana kegiatan pagi hari. Kalimat Terima kasih Tuban dan Atas karunia yang Kauberimenggambarkan bahwa bagi peserta didik Indonesia, fenomena pagi hari bukan sekadar fenomena alam biasa, tetapi merupakan anugerah Tuhan dan ada yang berkuasa dibalik semua peristiwa tersebut. Identitas religius lainnya terdapat pada kalimat Sebelum makan Siti berdoa dan Setelab makan Siti juga berdoa. Makan juga tidak dimaknai sebagai sebuah kebutuhan fisik semata, tetapi memiliki hubungan vertikal dengan Tuhan Pemberi Kehidupan. Kalimat sejenis berbunyi Sebelum makan Siti mencucitangan dan berdoa dan Siti bersyukur kepada Tuhan.

Identitas budaya lainnya yang digambarkan pada teks ini adalah sikap disiplin dan tidak berlebihan. Kedua identitas ini menunjukkan bahwa manusia Indonesia bersifat rasional. Pernyataan tersebut dapat disimak dalam kalimatkalimat: Sebelum berangkeat sekolah. Siti selalu sarapan.Siti sarapan dengan menu yang sehat.Sarapan membuat tubuh Siti kuat.Siti makan secukupnya.Identitas lain yang tampak dalam teks ini adalah identitas peduli lingkungan dan gotong royong sebagaimana tergambar pada teks berikut. Siswa petugas piket belum pulang.Mereka membersibkan kelas lebih dulu.Edo menyapu lantai.Siti membersibkan meja.Udin menghapus papan tulis.

Kosakata yang digunakan pada tema 4 merujuk pada penamaan tema, yaitu keluargaku dengan subtema anggota keluarga, kegiatan keluarga, keluarga besarku, dan kebersamaan dalam keluarga. Kosakata pada tema ini didominasi oleh kata kerja yang menunjukkan aktivitas dalam keluarga, seperti saling menyayangi, memiliki, membaca, mendampingi, menggambar, belajar, berolahraga, menyehatkan, dilakukan, memiliki, merapikan, membuat, menyiapkan, makan, membantu, menata, menyiapkan, mengisi, bekerja sama, membuat, suka, membantu, menyayangi, menghormati, menonton, dipeluk, bersyukur, mempunyai, berjasa, menjaga, berlomba, berusaha, bermain, bekerja sama, membantu, disayang, memperingati, 
membutubkan, memenangkan, dan saling mendukung. Semua kosakata di atas bermuara pada pembentukan keluarga yang harmonis, yang mengutamakan peran anggota keluarga sebagai bagian dari masyarakat sosial.

Sementara itu, kosakata benda terdiri atas kata ganti seperti mereka, keluarga, anggota keluarga, aku, kakak, kita dan kamu. Selebihnya kosakata benda menunjukkan makna orang dan benda yang hadir dalam kehidupan keluarga, seperti Udin, ayah, ibu, karunia Tuban, kegiatan, koran, senam irama, peraturan, rumah, mutiara, meja makan, piring, sendok, garpu, gelas, air minum, pekerjaan, Edo, televisi, orang tua, kemenangan, saudara, anak, tarik tambang, mereka, kesungguhan, dan lomba.

Selain kosakata di atas, tema 4 ini merangkaikan kosakata dalam bentuk kalimat yang membangun pesan identitas keindonesiaan. Pesan utama dalam tema ini adalah menyadarkan peserta didik sebagai bagian dari keluarga yang harus saling menyayangi. Kalimat Keluarga Udin saling menyayangi merupakan pernyataan yang hendak dibangun dalam kognisi, sikap, dan psikomotor peserta didik bahwa kehidupan keluarga harus dibagun berdasarkan kasih sayang.Demikian pula dengan kalimat Keluarga adalab karunia Tuban dan Aku menyayangi keluargaku menunjukkan bahwa keluarga merupakan anugerah yang harus dijaga dan diperlukan komitmen di antara anggota keluarga dalam membangun sebuah keluarga.

Teks juga memberikan gambaran peran dan posisi keluarga yang berkonsekuensi pada tanggung jawab yang harus diemban masing-masing anggota keluarga. Kalimat Anggota keluarga memiliki kegiatan yang berbeda-beda menguatkan pesan tersebut. Demikian pula keluarga dibangun berdasarkan tujuan bersama dan kebersamaan. KalimatKita ingin seluruh keluarga sehat memberikan referensi bahwa misi dan visi keluarga harus dibangun bersama. Untuk membangun sebuah keluarga yang baik, setiap anggota harus taat pada peraturan yang dibuat dalam keluarga tersebut. Hal ini ditegaskan dalam kalimat Setiap keluarga memiliki peraturan.

Bahasa yang digunakan dalam tema 4 menggambarkan bahwa peserta didik bukanlah manusia individualis yang tidak berakar pada keluarganya. Keluarga selain menjadi kehidupan sosial pertama juga menjadi inspirasi spiritual. Kalimat Kita harus bersyukur dan Kita mempunyai orang tua yang menyayangi kita menunjukkan bahwa keluarga bukan sekadar hadirnya manusia lain di luar diri kita, namun kita memiliki keterikatan secara sosial maupun secara spiritual. Hubungan sosial mengharuskan kita saling menyayangi dan menghormati di antara sesama anggota keluarga sedangkan hubungan spiritual mengharuskan kita berbakti kepada orang tua kita. Implikasi spiritual tersebut terdapat pada kalimat Anak yang suka membantu disayang Tuban. Demikian pula kalimat Ayah ibu telah berjasa kepada kita dan Tak ada yang menyayangi kita seperti ayah ibu menunjukkan berharganya kehadiran keluarga bagi seorang anak.

\section{Ideologi Identitas Budaya Keindonesiaan}

Ideologi yang dianalisis dalam buku ini tergambar melalui bahasa yang digunakan. Bahasa menjadi cermin dari ideologi penulisnya. Dalam buku teks, ideologi dibangun oleh pemerintah melalui penetapan kurikulum sebagai panduan penulisan buku teks. Tentu saja, penulisan buku ini mengacu pada rumusan kompetensi inti dan kompetensi dasar yang dirumuskan dalam bentuk sikap, pengetahuan, dan psikomotor.

Berdasarkan tujuan kurikulum 2013 dapat dirumuskan bahwa ideologi yang hendak dibangun pemerintah melalui pendidikan ini adalah mempersiapkan manusia Indonesia agar memiliki kemampuan hidup sebagai pribadi dan warga negara yang beriman, produktif, kreatif, inovatif dan afektif serta mampu berkontribusi pada kehidupan bermasyarakat, berbangsa, dan bernegara dan peradaban dunia (Permendikbud No. 
67 Tahun 2013). Sementara itu, ideologi dalam konteks kompetensi initi (KI) yang harus diraih siswa kelas 1 adalah (1) menerima dan menjalankan ajaran agama yang dianutnya; (2) memiliki prilaku jujur, disiplin, dan bertanggung jawab, santun, peduli, dan percaya diri dalam berinteraksi dengan keluarga, teman, dan guru; (3) memahami pengetahuan factual dengan cara mengamati (mendengar, melihat, membaca) dan menanya berdasarkan rasa ingin tahu tentang dirinya, makhluk ciptaan Tuhan dan kegiatannya, dan benda-benda yang dijumpainya di rumah dan di sekolah; (4) menyajikan pengetahuan factual dalam bahasa yang jelas dan logis, dalam karya yang estetis, dalam gerakan yang mencerminkan anak sehat, dan dalam tindakan yang mencerminkan anak yang beriman dan berakhlak mulia.

\section{Religius}

Ideologi religius (beriman) tercermin dalam teks buku ini dengan menggambarkan prilaku bersyukur terhadap karunia dan pemberian Tuhan dan prilaku berdoa. Hal ini sesuai pula dengan KI 1, yaitu menjalankan ajaran agama yang dianutnya. Ideologi religius ditekankan mengingat Indonesia merupakan negara yang menjamin kehidupan beragama warga negaranya dan berpandangan bahwa agama merupakan hal terpenting dalam kehidupan seseorang. Bahkan agama merupakan pusat (sumbu) persoalan-persoalan sosial lainnya. Sering kali penyelesaian persoalan sosial ditumpukan pada persoalan agama. Peserta didik yang diharapkan lahir melalui sistem pendidikan nasional adalah peserta didik yang beriman dan menjalankan ajaran agamanya. Di sini ditekankan bahwa agama menjadi spirit utama dalam menjalani kehidupan sosial. Agama menjadi perekat prilaku sosial peserta didik. Dalam teks buku ini, baik tema diriku, kegemaranku, kegiatanku, dan keluargaku bermuara pada pernyataan bahwa semua yang diperoleh dalam kehidupan merupakan karunia
Tuhan. Spiritual dibawa dan mengilhami setiap kegiatan sosial peserta didik.

\section{Sosial-Humanis}

Pribadi yang hendak dilahirkan dari pembelajaran berdasarkan kurikulum 2013 adalah peserta didik yang produktif, kreatif, inovatif dan afektif serta mampu berkontribusi pada kehidupan bermasyarakat, berbangsa, dan bernegara dan peradaban dunia. Hal ini sesuai dengan KI 2. Ideologi ini tercermin dalam prilaku peserta didik yang digambarkan dalam buku teks. Pada masing-masing tema: diriku, kegemaranku, kegiatanku, dan keluargaku digambarkan kebersamaan, kerjasama, dan sikap kasih sayang dalam menjalani setiap kegiatan. Perbedaan antarpribadi merupakan peluang untuk berbagi kasih sayang, kegemaran yang berbeda juga memberi ruang untuk membangun kerjasama, kegiatan yang berbeda-beda memungkinkan juga terbentuk kasih sayang, dan keluarga dengan berbagai agenda kegiatan memungkinkan terjadinya kerjasama di antara anggota keluarga. Dalam konteks budaya Indonesia sikap ini tercermin dalam prilaku gotong royong yang makin terkikis karena sikap individualis (Effendi, 2013: 1).

\section{Pluralis-toleransi}

Ideologi berikutnya yang hendak dikembangkan dalam buku teks ini adalah sikap pluralis-toleransi. Sikap ini berkembang sesuai dengan kenyataan bangsa ini. Melalui berbagai teks diungkapkan secara eksplisit sejak awal dalam buku ini, pluralitas menjadi pesan utama buku ini. Pemberian nama tokoh buku ini menunjukkan adanya pluralitas yang harus dipahami para siswa. Pemahaman akan pluralitas ini memungkinkan muncul sikap dan prilaku toleransi terhadap perbedaan. Pluralitas ini juga dikonstruksi secara sosial oleh masyarakat dengan pengaruh media massa (Pawito dan Kartono, 2013:111). Pemahaman terhadap perbedaan ini 
penting dimiliki peserta didik agar terbangun kesadaran bahwa perbedaan bukan masalah melainkan potensi untuk hidup lebih baik. Demikian pula dalam tema kegemaran, kegiatan, dan keluarga pluralitas ini dikembangkan secara baik dalam berbagai bentuk perbedaan keadaan dan tugas. Bahkan keluarga merupakan fondasi untuk mengembangan pluralitas sebelum peserta didik terjun ke masyarakat.

\section{Kemandirian}

Ideologi ini digambarkan melalui prilaku yang sesuai dengan aturan sehingga terbentuk sikap disiplin dari peserta didik. Tata nilai dan aturan yang disajikan secara terstruktur dan dilakukan secara tertib dalam buku ini menunjukkan bahwa peserta didik harus melakukan sesuatu secara benar berdasarkan aturan yang ada. Dalam tema kegemaran misalnya, berolahraga harus dilakukan berdasarkan aturan. Demikian pula dalam keluarga, setiap anggota keluarga harus menjalankan aturan berkeluarga secara baik. Dalam menjalankan kegiatan peserta didik harus melakukan aktivitas sesuai dengan waktunya. Inilah yang dimaksud rasional dalam konteks buku ini.

\section{SIMPULAN}

Penggunaan bahasa sebagai representasi identitas budaya keindonesiandigambarkan dalam bentuk kata dan kalimat atau wacana. Kosakata-kosakata yang digunakan sesuai dengan tema masingmasing memberikan rujukan pada setiap identitas yang hendak digambarkan. Kata teman atau keluarga, misalnya menggambarkan identitas sosial manusia Indonesia. Pada kata menyayangi dan menghormati dapat ditemukan identitas humanis manusia Indonesia. Pada kata berdoa, bersyukur, dan Tuban dapat dirujuk identitas religius yang hendak dibangun teks tersebut. Sementara itu, pada kata aturan dan menjalankan hendak digambarkan identitas disiplin dan rasional manusia Indonesia. Kata-kata tersebut pada umumnya dapat berbentuk nomina atau verbal. Dengan demikian kata dapat dijadikan acuan dalam menggambarkan identitas keindonesiaan. Selain itu, identitas ini lebih jelas digambarkan melalui rangkaian kalimat yang membangun wacana. Wacana yang digunakan pada umumnya berbentuk kalimat tunggal dan menggunakan strategi repetisi (pengulangan) untuk kata-kata tertentu, terutama yang berfungsi sebagai subjek.

Identitas budaya keindonesian yang digambarkan dalam buku teks mencakup identitas religius, sosio-humanis, toleransi, gotong royong, disiplin, optimis, dan rasional. Identitas religius ditunjukkan dengan sikap dan prilaku yang menggambarkan keyakinan terhadap Tuhan. Humanis, sosial, dan gotong royong ditunjukkan dengan sikap saling menolong dan kerjasama. Toleransi ditunjukkan dengan sikap menerima perbedaan yang ada di sekitar. Identitas disiplin ditunjukkan dengan prilaku yang sesuai dengan aturan dan kegiatan yang sistematis. Optimis dan rasional ditunjukkan dengan melakukan kegiatan yang bermanfaat dan mengetahui kegunaan dari kegiatan tersebut.Ideologi yang hendak dibentuk dalam buku teks sekaitan dengan identitas budaya keindonesianadalah bahwa buku teks menggambarkan cita-cita pendidikan nasional dan sesuai dengan tujuan kurikulum, yaitu untuk mempersiapkan manusia Indonesia agar memiliki kemampuan hidup sebagai pribadi dan warga negara yang beriman, produktif, kreatif, inovatif, dan afektif serta mampu berkontribusi pada kehidupan bermasyarakat, berbangsa, bernegara, dan peradaban dunia. Berdasarkan hal tersebut teks dalam buku ini membangun ideologi religius, ideologi sosio-humanis, ideologi pluralis-toleran, dan ideologi rasional. 


\section{DAFTAR RUJUKAN}

Anshori, DS. (2010). "Model Analisis Wacana Jurnalistik Berbasis Teknik Bingkai (Framing) untuk Meningkatkan Kompetensi Berwacana Siswa Sekolah Atas (SMA)". Bandung: SPs UPI. Disertasi Tidak Dipublikasikan.

Assagaf, L. dkk. (2013a). Diriku, Buku Tematike Terpadu Kurikulum 2013, Buku SD/MI Kelas 1. Jakarta: Kemendikbud.

Assagaf, L. dkk. (2013b). Kegemaranku, Buku Tematik Terpadu Kurikulum 2013, Buku SD/MI Kelas1. Jakarta: Kemendikbud.

Assagaf, L. dkk. (2013c). Kegiatanku, Buku Tematik. Terpadu Kurikulum 2013, Buku SD/MI Kelas 1. Jakarta: Kemendikbud.

Assagaf, L. dkk. (2013d). Keluargaku, Buku Tematik Terpadu Kurikulum 2013, Buku SD/MI Kelas 1. Jakarta: Kemendikbud.

Badara, A. (2012). Analisis Wacana, Teori, Metode, dan Penerapannya pada Wacana Media. Jakarta: Kencana.

Brown, G dan Yule, G. (1996). Analisis Wacana. Terjemahan I. Soetikno. Jakarta: Gramedia Pustaka Utama.

Chaika, E. (1982). Language the Social Mirror. Rowley: Newbury House Publisher

Clark, H.H. (1996). Using Language. Cambridge: Cambridge University Press.

Effendi, T.N. (2013). "Budaya Gotong Royong Masyarakat Dalam Perubahan Masyarakat Saat Ini”. Jurnal Pemikiran Sosiologi, Vol. 2 (1), 1-17.

Fairclough, N. (2003). Analysing Dicourse, Textual Analysis for Social Reseach. London: Routledge.

Gee, J.P. (1999). An Introduction to Discourse Analysis, Theory and Method. London: Routledge

Georgakapoulou, A. (2006). "Small and Large Identities in Narative
(Inter)action". Dalam Discourse and Identity (De Fina, A., Schiffrin, D. dan Bamberg, M., eds.). Cambridge: Cambridge University Press.

Heracleous, L. (2006). Discourse, Interpretation, Organization. Cambridge: Cambridge University Press.

Heryanto, A. (2000). Perlawanan dalam Kepatuhan. Bandung: Mizan Media Utama.

Hodge, R. dan Kress, G. (1993). Language as Ideology (second ed.). London: Routledge.

Hung Ng, S. dan Bradac, J.J. (1993). Power in Language, Verbal Communication and Social Influence. Newbury Park: Sage Publications

Kamus Besar Babasa Indonesia Edisi IV. (2008). Jakarta: Gramedia

Koenjtaraningrat. (1990). Manusia dan Kebudayaan di Indonesia. Jakarta: Penerbit Djambatan.

Mulyana, D. (2001). Metodologi Penelitian Kualitatif. Bandung: Rosdakarya.

Muhadjir, N. (2000). Metodologi Penelitian Kualitatif (edisi keempat). Yogyakarta: Rake Sarasin.

Moleong, L.J. (2002). Metodologi Penelitian Kualitatif. Bandung: Rosdakarya.

Pawito dan Kartono, D.T. (2013). "Konstruksi Identitas Kultural Masyarakat Pluralis Dalam Terpaan Globalisasi”. Mimbar, Jurnal Sosial dan Pembagunan, Vol. 23 (1), 111-120.

Perdana, D. I. (2013). Kurikulum dan Pendidikan di Indonesia, Proses Mencari Arah Pendidikan yang Ideal di Indonesia atau Hegemoni Kepentingan Semata?" Jurnal Pemikiran Sosiologi, Vol. 2 (1), 63-74.

Pikiran Rakyat. "Jawa Barat Termasuk Daerah Rawan Konflik". 6 Januari 2014, hal. 1

Pikiran Rakyat. "DPR tak Berjuang untuk Rakyat". 6 Januari 2014, hal. 2. 
Schiffrin, D. (2006). "From Linguistic Reference to Social Reality". Dalam Discourse and Identity (De Fina, A., Schiffrin, D. dan Bamberg, M., eds.). Cambridge: Cambridge University Press.

\section{UCAPAN TERIMA KASIH}

Peneliti mengucapkan terima kasih kepada Rektor UPI atas kesempatan melakukan penelitian ini melalui skim Pembinaan dan Pengembangan Kelompok Bidang Keilmuan tahun anggaran 2014, dan kepada Jurnal Pendidikan Bahasa dan Sastra atas pemuatan artikel hasil penelitian ini. 